\title{
Acute Activation of the Renal Betaine/GABA Transporter in Response to a Decrease in Extracellular Calcium
}

\author{
Nehal R. Parikh, Cherissa L. Vaughn, Lagina L. Williams, and Stephen A. Kempson \\ Department of Cellular \& Integrative Physiology, Indiana University School of Medicine, MS-385, 635 Barnhill Drive, \\ Indianapolis, IN 46223, USA \\ Correspondence should be addressed to Stephen A. Kempson; skempson@iupui.edu
}

Received 24 August 2012; Accepted 18 September 2012

Academic Editors: G.-R. Li and A. Peres

Copyright (c) 2013 Nehal R. Parikh et al. This is an open access article distributed under the Creative Commons Attribution License, which permits unrestricted use, distribution, and reproduction in any medium, provided the original work is properly cited.

The betaine/GABA transporter (BGT1) is important for osmoprotection in kidney medullary cells. We previously reported an acute $(30 \mathrm{~min})$ increase in extracellular $\mathrm{Ca}^{2+}$ caused dose dependent inhibition of BGT-1 in renal MDCK cells. To determine if extracellular $\mathrm{Ca}^{2+}$ might be a local regulator of BGT-1, we have tested the response to low $\mathrm{Ca}^{2+}$ serum-free growth medium (LCM, $0.05 \mathrm{mM} \mathrm{Ca}^{2+}$ ). Chronic treatment (8-24 h) of MDCK cell monolayers completely blocked hypertonic adaptation of BGT1 and disrupted tight junctions. In contrast, acute treatment activated BGT1 transport within 30 min in MDCK cells previously adapted to hypertonic growth medium containing normal $\mathrm{Ca}^{2+}(1.6 \mathrm{mM})$. Activation was significant after $60-90 \mathrm{~min}$ and was independent of medium osmolarity. Peak transport was increased $50 \%$ in isotonic LCM and $100 \%$ in hypertonic (500 mOsm) LCM over controls. The activation was reversed by restoration of normal $\mathrm{Ca}^{2+}$. Perfusion of Fura-2-loaded MDCK cells with LCM decreased intracellular $\mathrm{Ca}^{2+}$ by $31 \%$ within 6-7 min. Inclusion of staurosporine $(0.6 \mu \mathrm{M})$, a protein kinase $\mathrm{C}$ inhibitor, potentiated the action of LCM. We suggest that activation of BGT1 by LCM may be due in part to inhibition of protein kinase C.

\section{Introduction}

Adaptation to chronic hypertonic stress by nephron segments in the kidney inner medulla involves cellular accumulation of organic osmolytes that do not disturb cell function. Betaine is an important osmolyte and it also may act as a protein chaperone to help protect intracellular proteins from the denaturing effects of medullary solutes such as urea and ammonia. Cell uptake of betaine is mediated by the betaine/GABA transporter (BGT1) located primarily in the basolateral plasma membrane [1]. BGT1 also can accept GABA as a substrate but betaine is the principal substrate in the kidney $[2,3]$.

Up- and down-regulation of BGT1 by changes in extracellular osmolarity is slow, requiring almost $24 \mathrm{hr}$, likely due to the need for de novo synthesis and intracellular trafficking. The response to hypertonic stress has been studied in great detail in the MDCK established cell line derived from the renal medulla $[4,5]$. However, we have previously demonstrated relatively rapid down-regulation (within $30 \mathrm{~min}$ ) of BGT1 transport in MDCK cells in response to extracellular ATP, adenosine, nitric oxide, and calcium [6-8]. Inhibition of BGT1 transport by calcium was reproduced by a phorbol ester (phorbol myristate 13 acetate) and a diacylglycerol analog (dioctanoglycerol), suggesting a role for protein kinase $\mathrm{C}$ and was accompanied by internalization of BGT1 from the plasma membrane [7].

The present study is focused on the effects of low extracellular calcium to further establish a role for calcium in acute regulation of the renal BGT1 transport protein. The system A amino acid transporter ("alanine preferring") was used as a control because, like BGT1, it is primarily present in the basal-lateral plasma membrane of MDCK cells $[9,10]$. Unlike BGT1, it is upregulated much more rapidly (within 5-6 hr) by hypertonic stress [11].

\section{Methods}

Normal and low calcium solutions were prepared as described previously in detail [7]. MDCK cells (CCL-34, American Type Culture Collection, Rockville, MD, USA) were used between passages 15 and 40 and were grown in a 1:1 mixture of DMEM-Ham's F12 containing 10\% 
bovine calf serum penicillin $(100 \mathrm{IU} / \mathrm{mL})$ and streptomycin $(100 \mu \mathrm{g} / \mathrm{mL})$. Transport activities of BGT1 and system A in MDCK cells were measured as $\mathrm{Na}^{+}$-dependent uptakes of $\left[{ }^{3} \mathrm{H}\right] \mathrm{GABA}$ and $\left[{ }^{14} \mathrm{C}\right]$ methylaminoisobutyric acid, respectively, by whole cells $[11,12]$. Intracellular calcium was measured with fura-2 imaging, as described previously [7], using serum-free solutions and without phenol red to minimize background and cell autofluorescence. MDCK cells were grown on coverglasses and fura-2, a $\mathrm{Ca}^{2+}$-sensitive probe, was loaded as the acetoxymethyl ester $(2.5 \mu \mathrm{M}$, Invitrogen/Molecular Probes). Cells were studied at room temperature using the InCa imaging system (Intracellular Imaging, Cincinnati, OH, USA) which was used and calibrated as described previously [7]. MDCK cells on coverglasses were prepared for confocal microscopy by fixation in $4 \%$ paraformaldehyde, permeabilization in $0.2 \%$ Triton X100 , incubation for 60 min with primary antibodies $(1: 100$ dilution) to E-cadherin, ZO1, or BGT1, followed by $30 \mathrm{~min}$ incubation with goat anti-rabbit IgG conjugated to FITC or Texas Red (Jackson Immuno Research, West Grove, PA, USA). Some cells were counterstained with propidium iodide to visualize nuclei.

Data are expressed as the mean \pm SD of at least three separate experiments. In each transport experiment the mean value $(n=1)$ was derived from triplicate measurements, where appropriate, different groups were compared by Student's $t$-test or by analysis of variance and Tukey's test for multiple comparisons.

\section{Results and Discussion}

Initial studies were performed on MDCK cells grown on permeable supports [7] to allow specific assay of transport activity in the basolateral plasma membrane, the primary location of BGT1 in both MDCK cells and the renal medullary collecting duct $[1,13]$. Long-term exposure $(8$ or $24 \mathrm{hrs}$ ) to hypertonic growth medium ( $500 \mathrm{mOsm})$ containing low $\mathrm{Ca}^{2+}$ concentration $(0.05 \mathrm{mM}$, LCM) disrupted the tight junctions in MDCK cells, as expected. The calcium switch technique is a standard procedure for disrupting tight junctions in MDCK cells $[14,15]$. The cells were rounded and many had detached from the substrate. The distribution of E-cadherin protein, normally present in tight junctions at the plasma membrane of epithelial cells [16], was primarily intracellular (Figure 1, right), in contrast to cells in normal hypertonic growth medium (Figure 1, left). Switching cells from normal isotonic growth medium (1.6. $\mathrm{mM} \mathrm{Ca}^{2+}$ ) to hypertonic LCM for 8 or $24 \mathrm{~h}$ completely prevented the normal upregulation of BGT-1 transport by hypertonic stress (Figure 2(a)). This may occur because the tight junctions normally act as "signposts" to direct intracellular protein traffic [16-19]. Direct visualization of BGT1 protein distribution in cells exposed to hypertonic LCM confirmed that BGT1 protein was primarily intracellular and not inserted in the plasma membrane (Figure 2(b), bottom). In contrast, BGT1 was primarily in the plasma membrane of cells exposed to normal hypertonic medium (Figure 2(b), top). Thus, even though the hypertonic stimulus for upregulation of BGT1
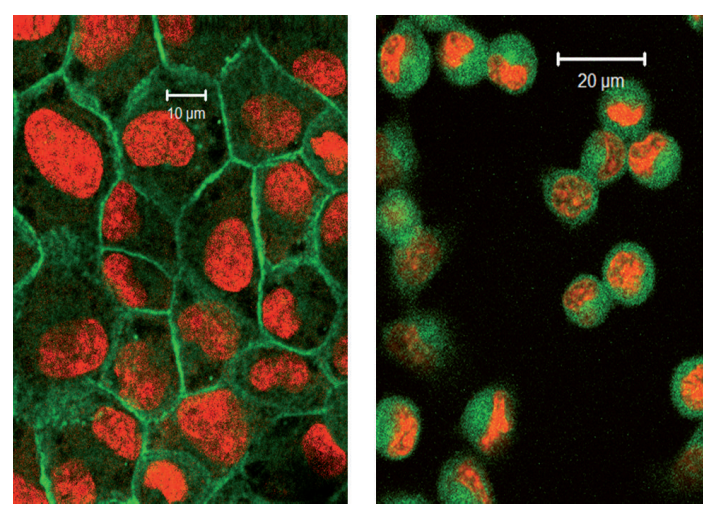

FIGURE 1: Distribution of E-cadherin (green) in filter-grown MDCK cell monolayers after $8 \mathrm{~h}$ of hypertonic stress $(500 \mathrm{mOsm})$ in either normal (left) or low $\mathrm{Ca}^{2+}$ (right) growth medium. Nuclei were stained with propidium iodide (red).

was present, the protein was not inserted (or retained) in the plasma membrane when tight junctions were disrupted.

Similar findings were present in MDCK cells grown on plastic (not shown) and this model, employed in earlier studies of calcium regulation [7], was used in all further experiments for greater convenience. Surprisingly, when cells previously treated for $24 \mathrm{~h}$ with normal hypertonic medium were incubated for 30-60 min with hypertonic LCM there was an additional $50-100 \%$ upregulation of BGT1 transport. This was detected when either betaine (Figure 3(a)) or GABA (Figure 3(b)) was used as the substrate for BGT1. Activation by LCM was reversed completely within $2 \mathrm{~h}$ after returning cells to normal hypertonic medium (Figure 3(b)). Amino acid transport via system A, also located on the basolateral plasma membrane $[9,10]$, showed a similar rapid increase in response to LCM that was decreased by subsequent return to normal hypertonic medium (Figure 4(a)). This indicates that the acute stimulation of transport by hypertonic LCM is not specific to BGT1. As discussed elsewhere [11] the hypertonic activation of system A transport is much more rapid than BGT1 and likely represents an intermediate step in adaptation to hypertonic stress. It is reasonable to expect that activation of system A also would be sensitive to extracellular calcium. The acute stimulation of BGT1 by LCM also was observed under isotonic conditions (Figure 4(b)) suggesting the mechanism was not dependent on hypertonic stress.

Monitoring distribution of $\mathrm{ZO} 1$, another tight junction protein [14], revealed that brief exposure $(30-45 \mathrm{~min})$ to LCM was sufficient for disrupting tight junctions in MDCK cells. Note the loss of ZO1 from plasma membranes and accumulation inside the cell in response to brief LCM treatment compared to the controls (Figure 5). This raises the question of how BGT1 can be activated by LCM if tight junctions are undergoing disassembly.

In an attempt to resolve this we first examined the effect of calcium switch on intracellular calcium using Fura-2 loaded cells. Intracellular calcium was relatively stable during perfusion of MDCK monolayers with normal serum-free medium $\left(1.6 \mathrm{mM} \mathrm{Ca}^{2+}\right)$ containing no phenol red. When this 


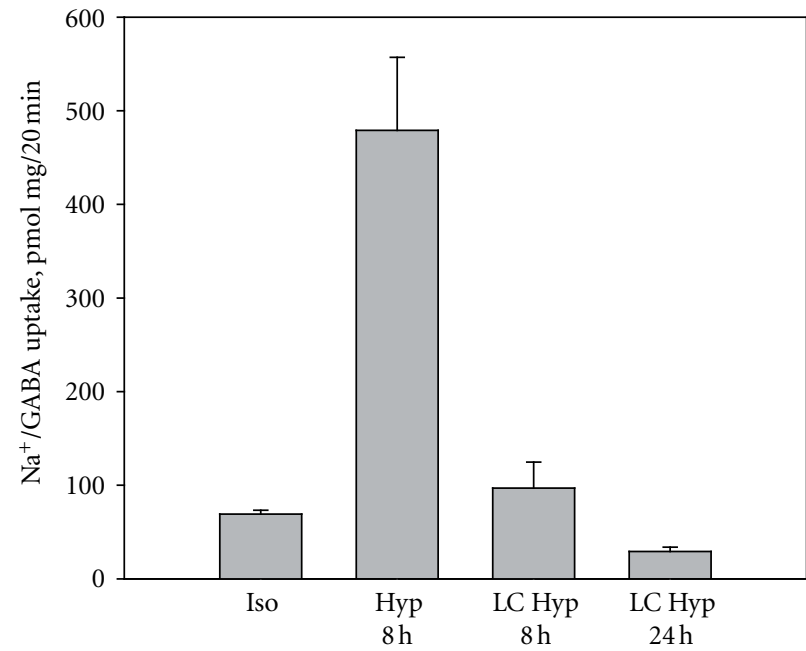

(a)
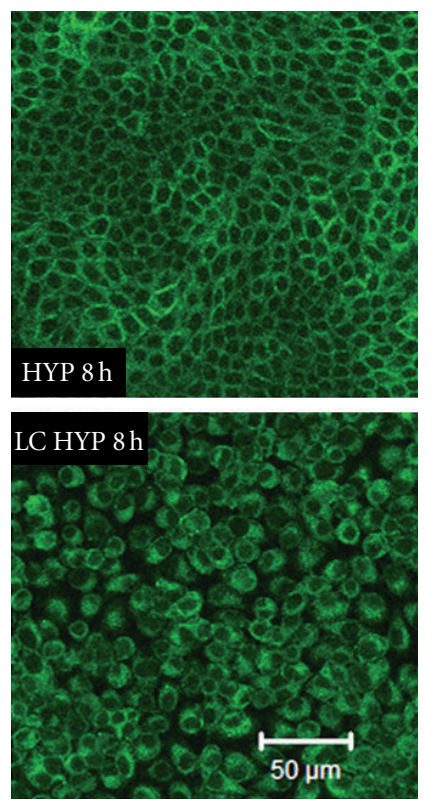

(b)

FIGURE 2: (a) Chronic hypertonic stress upregulated BGT1 transport, measured as $\mathrm{Na}^{+}$-dependent uptake of GABA, but was blocked in low $\mathrm{Ca}^{2+}$ (LC) hypertonic growth medium (mean \pm SD from 3 separate experiments). (b) This was accompanied by separation and rounding up of the MDCK cells and intracellular accumulation of BGT1 protein (bottom), compared to controls in normal hypertonic medium (top).

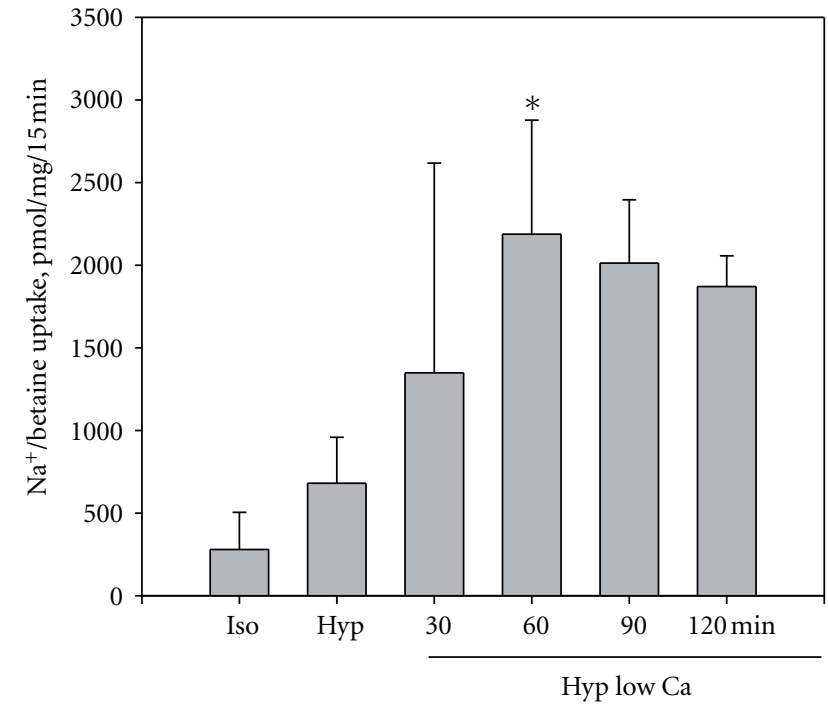

(a)

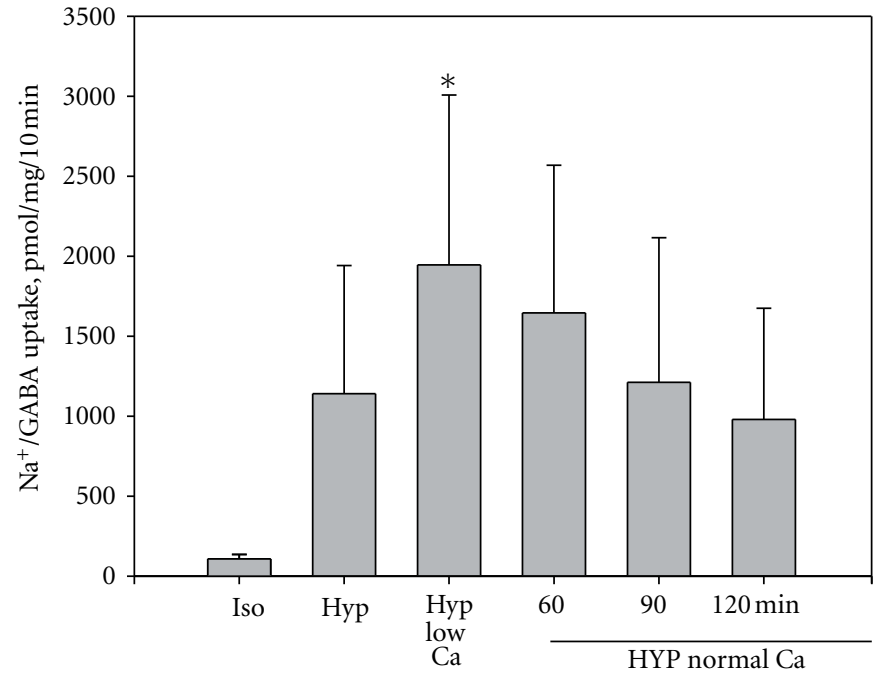

(b)

FIgURE 3: Additional activation of BGT1 transport in plastic-grown MDCK monolayers by acute exposure to low $\mathrm{Ca}^{2+}$ hypertonic growth medium following overnight $\left(16 \mathrm{~h}\right.$ ) adaptation to normal hypertonic medium. (a) $\mathrm{Na}^{+}$-dependent betaine transport was significantly activated after $60 \mathrm{~min}$ in low $\mathrm{Ca}^{2+}$ medium compared to normal hypertonic controls. (b) Activation of $\mathrm{Na}^{+}$-dependent GABA transport by 60 min exposure to hypertonic low $\mathrm{Ca}^{2+}$ medium was reversed completely within $2 \mathrm{~h}$ after return to normal hypertonic growth medium. ${ }^{*}$ Significantly different $(P<0.05)$ compared to Hyp controls. Data are mean \pm SD from 5 separate experiments.

was replaced with serum-free LCM $\left(0.05 \mathrm{mM} \mathrm{Ca}^{2+}\right)$ there was a prompt decrease in intracellular $\mathrm{Ca}^{2+}$ that continued to fall as the perfusion was continued for about $400 \mathrm{sec}$. This fall was reversed rapidly and completely by reperfusion with normal calcium medium (Figure 6(a)). A summary of peak values is shown in Figure 6(b), based on determinations in 22 different cells, and reveals an overall $31 \%$ decrease in response to LCM.

Final studies tested if the short-term activation of BGT1 was related to acute changes in intracellular $\mathrm{Ca}^{2+}$. Previous studies have shown that an increase in extracellular $\mathrm{Ca}^{2+}$ leads 


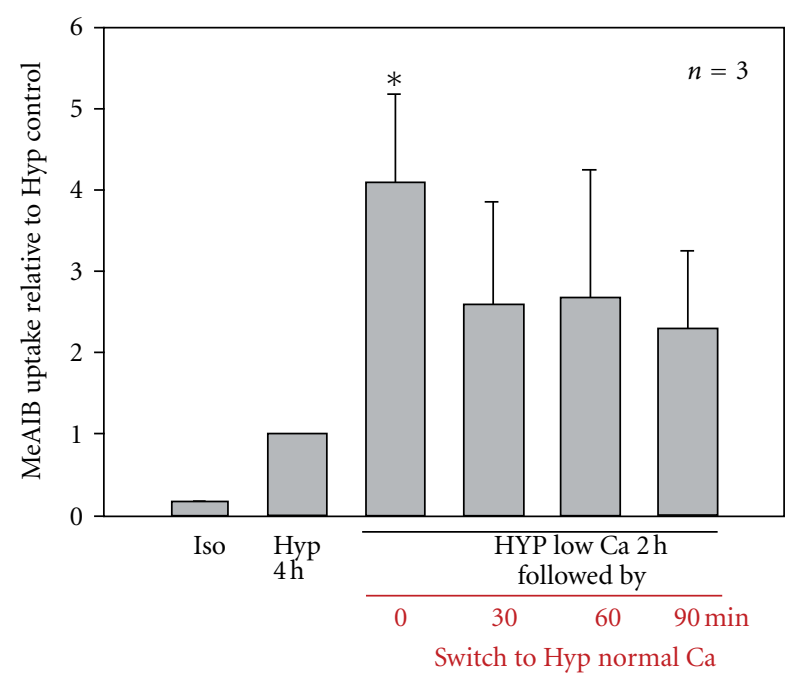

(a)

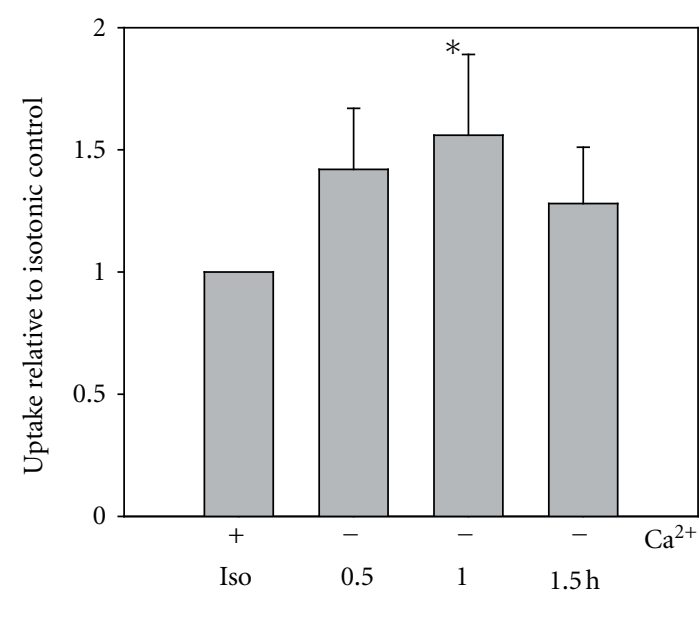

(b)

Figure 4: (a) System A amino acid transport was activated 4-fold by Hyp stress ( $500 \mathrm{mOsm}$ ) for $4 \mathrm{~h}$ and treatment with hypertonic low $\mathrm{Ca}^{2+}$ medium for $2 \mathrm{~h}$ produced a further 3.5 -fold increase. (b) Activation of BGT1 transport by low Ca ${ }^{2+}$ medium was less marked but still detectable after $1 \mathrm{~h}$ under isotonic (Iso) conditions. * Significantly different $(P<0.05)$ from Hyp or Iso controls. Data are mean \pm SD from 3-4 separate experiments.

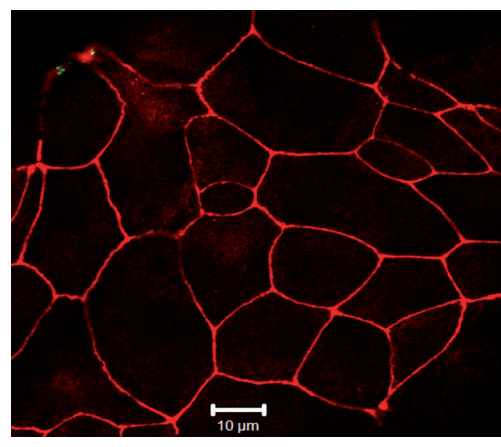

(a)

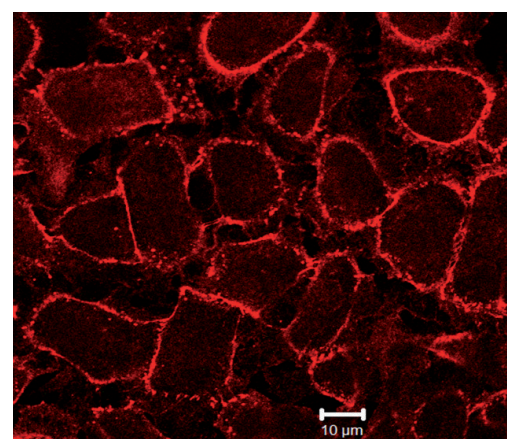

(b)

Figure 5: Loss of MDCK tight junctions after just $45 \mathrm{~min}$ in hypertonic low $\mathrm{Ca}^{2+}$ growth medium is illustrated by cell separation and intracellular accumulation of ZO1 protein (red, (b)) compared to controls in normal hypertonic growth medium (a).

to an increase in intracellular $\mathrm{Ca}^{2+}$ which activates protein kinase C. This is associated with the endocytic removal of BGT1 from the plasma membrane and into the cell interior [7]. Clearly the decrease in extracellular $\mathrm{Ca}^{2+}$ also decreases intracellular $\mathrm{Ca}^{2+}$ (Figure 6), which may reduce or switch off endocytosis of BGT1. If exocytic insertion of BGT1 into the plasma membrane continues, this would explain the acute upregulation of BGT1 transport in LCM following hypertonic upregulation. The previous adaptation to hypertonic treatment ensures that increased amounts of BGT1 protein are already available within the cell, as we have shown previously [20]. However, previous hypertonic upregulation may not be needed as shown by the activation by LCM under isotonic conditions (Figure 4(b)).

Consistent with a proposed role for protein kinase $\mathrm{C}$ is the observation that addition of staurosporine, an inhibitor of protein kinase $\mathrm{C}$, also activated BGT1 transport. As shown in Figure 7, a two-hour treatment with hypertonic LCM containing staurosporine $(0.6 \mu \mathrm{M})$ further increased the activation of BGT1 compared to hypertonic LCM alone. Lastly, a two-hour treatment with hypertonic normal calcium medium containing staurosporine $(0.6 \mu \mathrm{M})$ also significantly increased BGT1 transport to $3541 \pm 481$ compared to $1910 \pm$ $199 \mathrm{pmol}$ betaine/mg protein/20 min in hypertonic controls (mean $\pm \mathrm{SD}, P<0.05, n=4$ ). This confirms that inhibition of protein kinase $C$ is associated with activation of BGT1 transport activity. Loss of tight junction integrity apparently does not interfere with the acute action of LCM. This may be consistent with a mechanism that leads to reduced endocytic removal of BGT1 from the plasma membrane, rather than increased exocytic delivery which may be more dependent on directional cues by tight junctions.

Another possible mechanism for the acute upregulation of BGT1 could be that the decrease in intracellular $\mathrm{Ca}^{2+}$ 


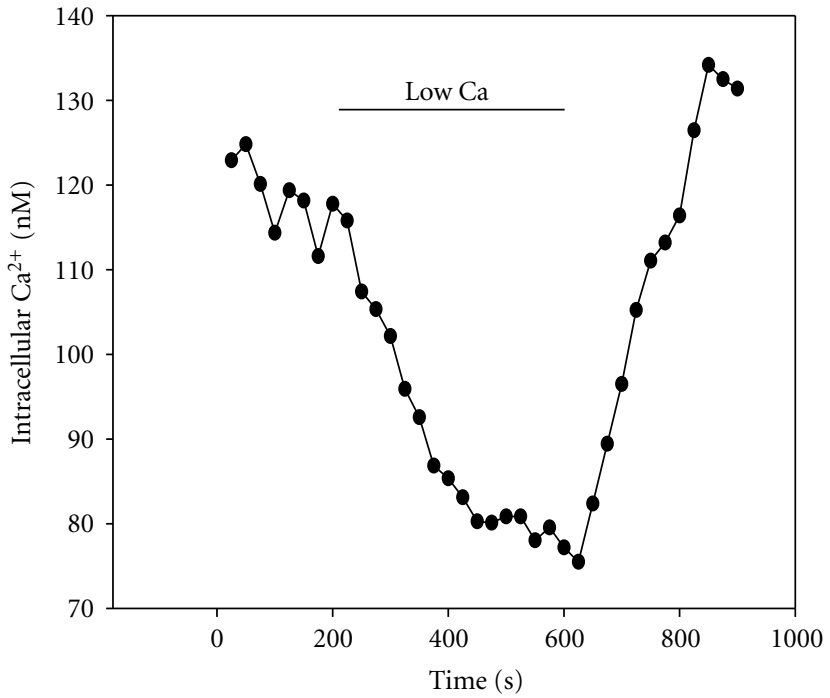

(a)

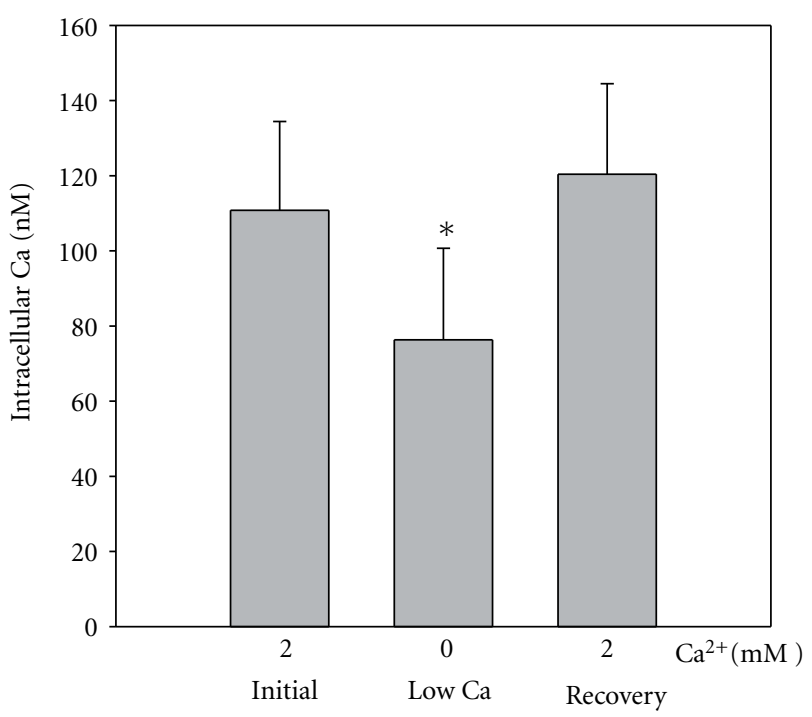

(b)

FIGURE 6: (a) Superperfusion of MDCK monolayers with low $\mathrm{Ca}^{2+}$ medium produced a rapid decrease in intracellular calcium concentration, based on fura-2 imaging, which was reversed completely by switching back to normal calcium medium. (b) Comparison of the peak values showed the fall in intracellular calcium was statistically significant. ${ }^{*} P<0.005$. Data are mean \pm SD from 22 cells.

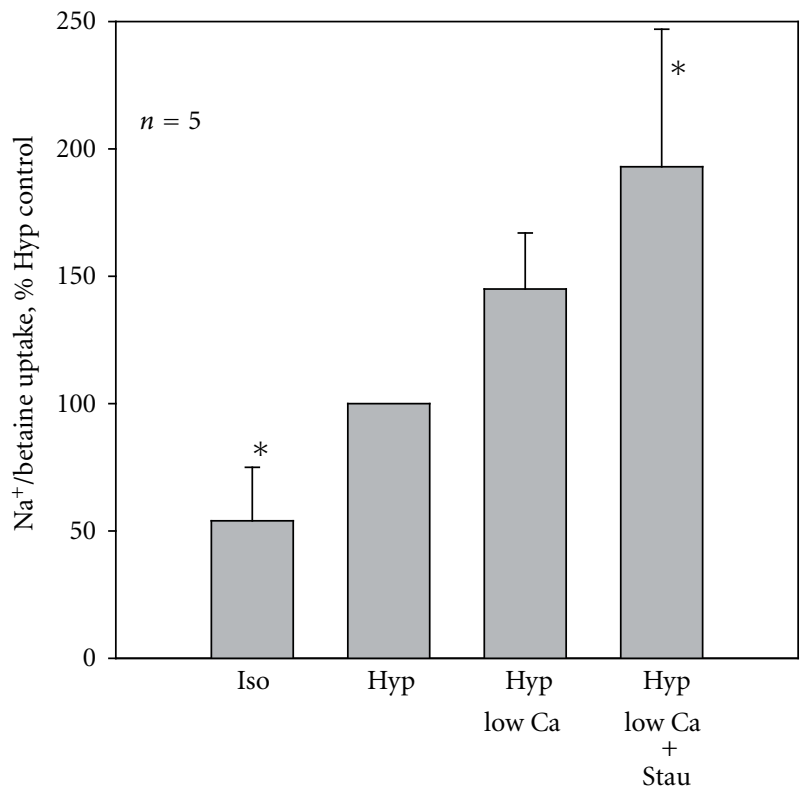

FIGURE 7: Inclusion of staurosporine $(0.6 \mathrm{mM}$, Stau) in hypertonic low $\mathrm{Ca}^{2+}$ medium potentiated the activation of BGT1 transport activity by hypertonic low $\mathrm{Ca}^{2+}$ medium alone. Treatment with hypertonic low $\mathrm{Ca}^{2+}$ medium \pm Stau was for $2 \mathrm{~h}$ following overnight hypertonic stress $(500 \mathrm{mOsm}) .{ }^{*}$ Significantly different $(P<0.05)$ from Hyp controls. Data are mean \pm SD from 5 separate experiments.

causes direct activation of the betaine/GABA transporter after it has been inserted into the plasma membrane, either in minor amounts during isotonic conditions or much larger amounts during hypertonic stress. Hypertonic stress is not required for the acute upregulation by LC medium, and this also would explain why acute activation by LC medium can occur even though tight junctions appear to be disrupted (Figure 5). However, this explanation appears less likely since we previously demonstrated that calcium ions have no direct effect on BGT1 transport as determined in isolated plasma membrane vesicles from MDCK cells [7].

Lastly, it is of interest to note that calcium has been reported to enhance the expression and activity of TonEBP, the transcription factor that regulates expression of osmosensitive genes, such as BGT1, in many cell types [21, 22]. This suggests another possible regulatory mechanism and additional work is needed to directly determine the intracellular mechanism of calcium action on BGT1. The physiological relevance of acute regulation of BGT1 by $\mathrm{Ca}^{2+}$ remains speculative. During normal renal function it could be a mechanism for the fine tuning of BGT1 transport during fluctuations in medullary hypertonicity through one or more of the mechanisms discussed here.

\section{Acknowledgments}

This work was supported by the Life-Health Science Internship at IUPUI (NP) and the American Heart Association Midwest Affiliate (SK).

\section{References}

[1] Y. Zhou, S. Holmseth, R. Hua et al., "The betaine-GABA transporter (BGT1, slc6a12) is predominantly expressed in the liver and at lower levels in the kidneys and at the brain surface," American Journal of Physiology, vol. 302, pp. F316-F328, 2012.

[2] M. B. Burg, "Molecular basis of osmotic regulation," American Journal of Physiology, vol. 268, no. 6, pp. F983-F996, 1995. 
[3] M. B. Burg, E. D. Kwon, and E. M. Peters, "Glycerophosphocholine and betaine counteract the effect of urea on pyruvate kinase," Kidney International Supplements, vol. 50, no. 57, pp. S100-S104, 1996.

[4] W. Neuhofer, S. K. Woo, K. Y. Na et al., "Regulation of TonEBP transcriptional activator in MDCK cells following changes in ambient tonicity," American Journal of Physiology, vol. 283, no. 6, pp. C1604-C1611, 2002.

[5] J. Dukes, P. Whitley, and A. Chalmers, "The MDCK variety pack: choosing the right strain," BMC Cell Biology, vol. 12, article 43, 2011.

[6] S. Kempson, N. Thompson, L. Pezzuto, and H. Glenn Bohlen, "Nitric oxide production by mouse renal tubules can be increased by a sodium-dependent mechanism," Nitric Oxide, vol. 17, no. 1, pp. 33-43, 2007.

[7] S. A. Kempson, J. M. Edwards, and M. Sturek, "Inhibition of the renal betaine transporter by calcium ions," American Journal of Physiology, vol. 291, no. 2, pp. F305-F313, 2006.

[8] S. Kempson, "Upregulation of betaine/GABA transporter BGT1 by nitric oxide in renal cells," Journal of the American Society of Nephrology, vol. 17, abstract 95A, 2006.

[9] P. Boerner, M. Evans-Layng, H. S. U, and M. H. Saier, "Polarity of neutral amino acid transport and characterization of a broad specificity transport activity in a kidney epithelial cell line, MDCK," The Journal of Biological Chemistry, vol. 261, no. 30, pp. 13957-13962, 1986.

[10] M. Horio, A. Yamauchi, T. Moriyama, E. Imai, and Y. Orita, "Osmotic regulation of amino acids and system A transport in Madin-Darby canine kidney cells," American Journal of Physiology, vol. 272, no. 3, pp. C804-C809, 1997.

[11] S. A. Kempson, "Differential activation of system A and betaine/GABA transport in MDCK cell membranes by hypertonic stress," Biochimica et Biophysica Acta, vol. 1372, no. 1, pp. 117-123, 1998

[12] J. G. Chen, M. Coe, J. A. McAteer, and S. A. Kempson, "Hypertonic activation and recovery of system a amino acid transport in renal MDCK cells," American Journal of Physiology, vol. 270, no. 3, pp. F419-F424, 1996.

[13] A. Yamauchi, H. M. Kwon, S. Uchida, A. S. Preston, and J. S. Handler, "Myo-inositol and betaine transporters regulated by tonicity are basolateral in MDCK cells," American Journal of Physiology, vol. 261, no. 1, pp. F197-F202, 1991.

[14] E. McNeil, C. T. Capaldo, and I. G. Macara, "Zonula occludens1 function in the assembly of tight junctions in Madin-Darby canine kidney epithelial cells," Molecular Biology of the Cell, vol. 17, no. 4, pp. 1922-1932, 2006.

[15] E. Sabath, H. Negoro, S. Beaudry et al., "G $\alpha 12$ regulates protein interactions within the MDCK cell tight junction and inhibits tight-junction assembly," Journal of Cell Science, vol. 121, no. 6, pp. 814-824, 2008.

[16] D. B. N. Lee, E. Huang, and H. J. Ward, “Tight junction biology and kidney dysfunction," American Journal of Physiology, vol. 290, no. 1, pp. F20-F34, 2006.

[17] K. Shin, V. C. Fogg, and B. Margolis, "Tight junctions and cell polarity," Annual Review of Cell and Developmental Biology, vol. 22, pp. 207-235, 2006.

[18] I. Mellman and W. J. Nelson, "Coordinated protein sorting, targeting and distribution in polarized cells," Nature Reviews Molecular Cell Biology, vol. 9, no. 11, pp. 833-845, 2008.

[19] I. S. Näthke, L. Hinck, J. R. Swedlow, J. Papkoff, and W. J. Nelson, "Defining interactions and distributions of cadherin and catenin complexes in polarized epithelial cells," Journal of Cell Biology, vol. 125, no. 6, pp. 1341-1352, 1994.

[20] S. A. Kempson, V. Parikh, L. Xi, S. Chu, and M. H. Montrose, "Subcellular redistribution of the renal betaine transporter during hypertonic stress," American Journal of Physiology, vol. 285, no. 5, pp. C1091-C1100, 2003.

[21] S. D. Lee, S. Youn Choi, S. Woo Lim et al., "TonEBP stimulates multiple cellular pathways for adaptation to hypertonic stress: organic osmolyte-dependent and -independent pathways," American Journal of Physiology, vol. 300, no. 3, pp. F707-F715, 2011.

[22] J. A. Halterman, H. M. Kwon, and B. R. Wamhoff, "Tonicityindependent regulation of the osmosensitive transcription factor TonEBP (NFAT5)," American Journal of Physiology, vol. 302, pp. C1-C8, 2012. 

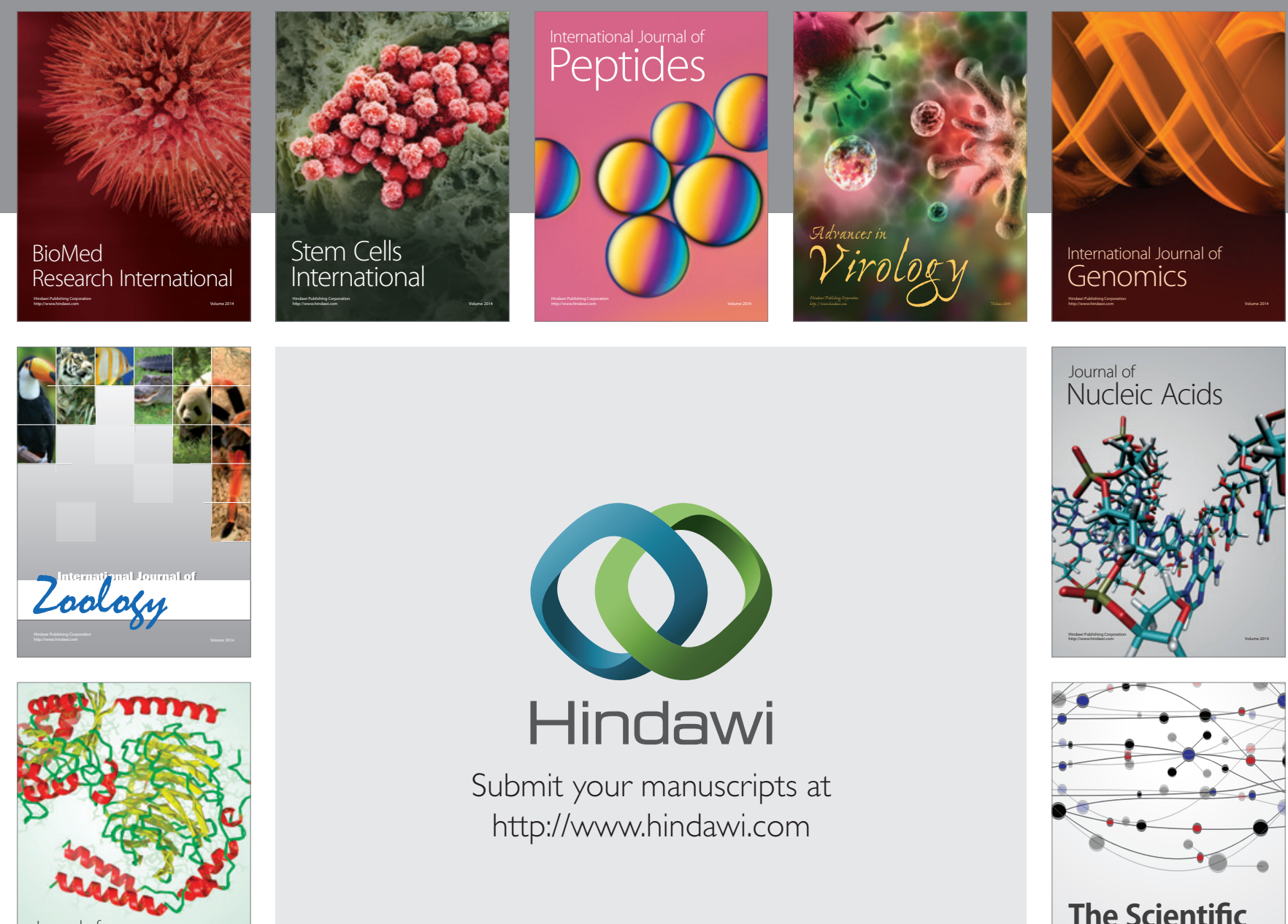

Submit your manuscripts at

http://www.hindawi.com

Journal of
Signal Transduction
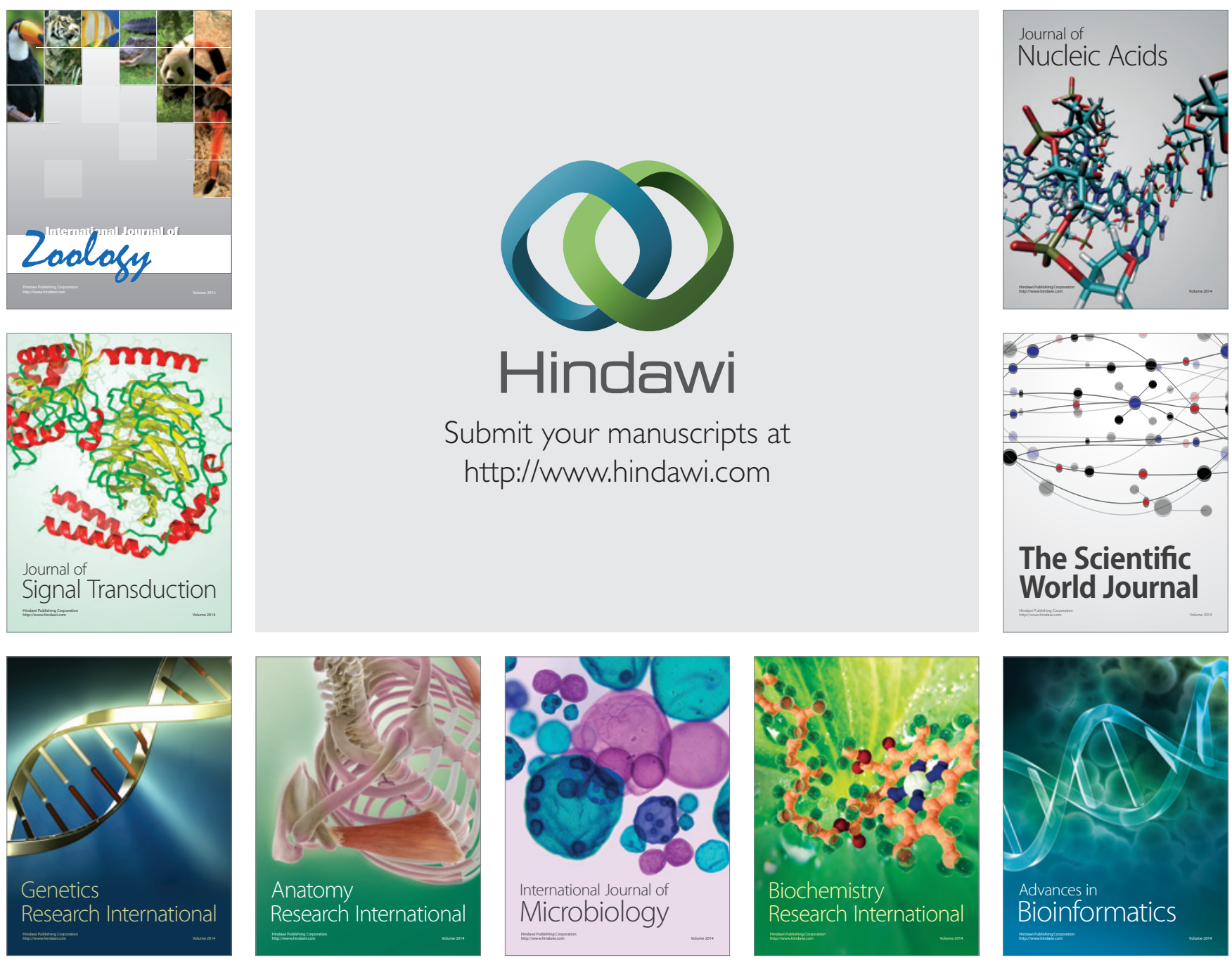

The Scientific World Journal
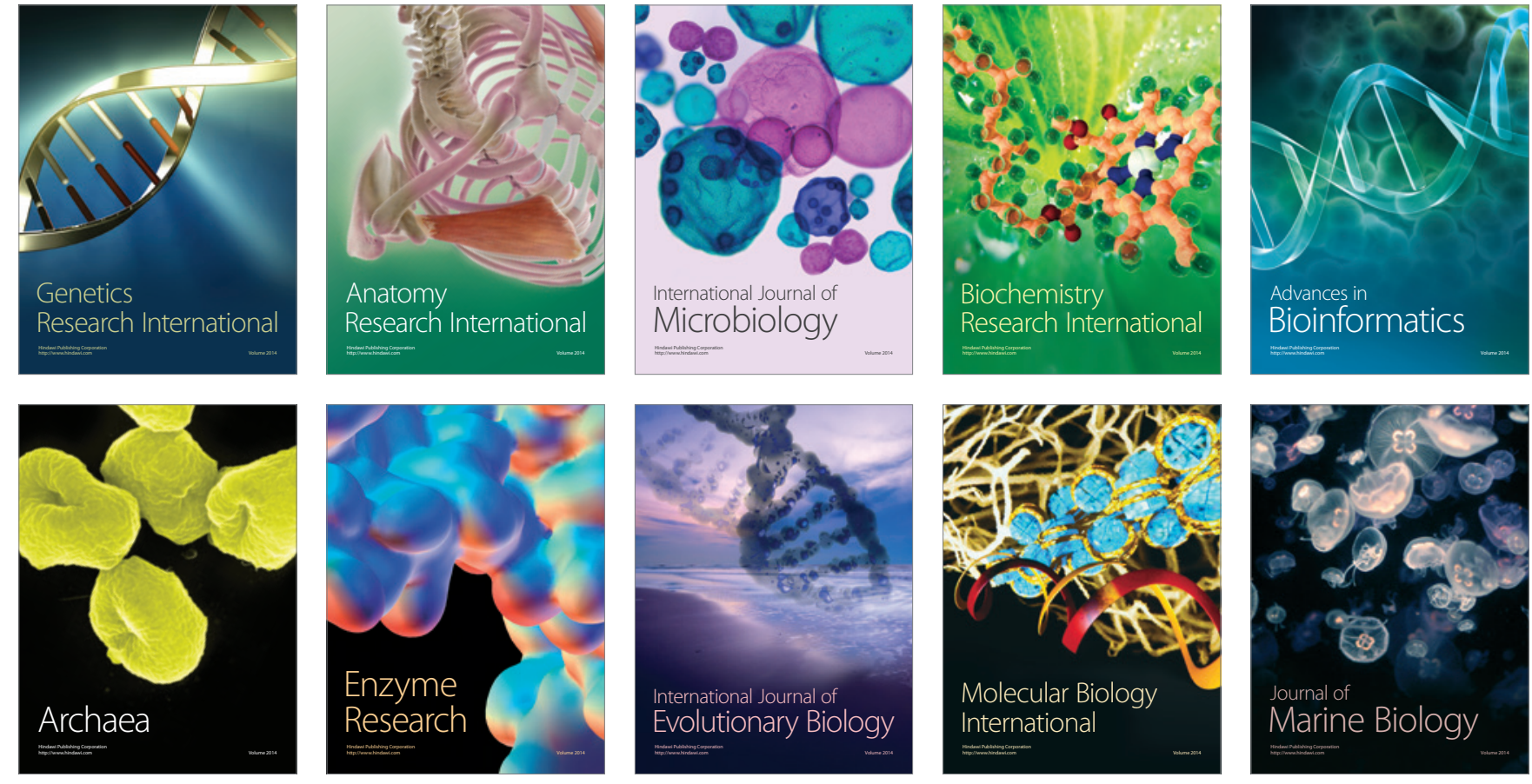